\title{
Factors Affecting the Income of Vietnamese Peasants: A Case in Tra Vinh Province
}

\author{
Ha Hong Nguyen ${ }^{1} \&$ Trung Thanh Nguyen ${ }^{1}$ \\ ${ }^{1}$ Department of Finance and Banking, Tra Vinh University, Viet Nam \\ Correspondence: Ha Hong Nguyen, Ph.D. Head of Department of Finance and banking, Tra Vinh University, 126 \\ Nguyen Thien Thanh Str, Ward 5, Tra Vinh city, Tra Vinh Province, Viet Nam.
}

Received: May 15, 2019

doi:10.5430/rwe.v10n1p54
Accepted: June 9, 2019

Online Published: June 12, 2019

URL: https://doi.org/10.5430/rwe.v10n1p54

\begin{abstract}
Studying the factors affecting the income of Vietnamese peasants: A case in Tra Vinh province, by data collection method of 170 peasants' households in 4 districts: Cau Ngang, Cang Long, Chau Thanh and Tieu Can in Tra Vinh province, Vietnam. The authors use multivariate regression analysis method. The study has found the factors such as gender of households's heads, ages of households' heads, education levels, the number of family members, dependency rates, application of technical advances, production areas affecting the income of peasants in these areas. Since then, the study has implied a policy to improve the income of peasants. For example, it could be very important for us to focus on training science and technology in agriculture, diversify crops and livestock in agriculture, improve techniques and enhance education levels to increase income for peasants in Tra Vinh province in the future.
\end{abstract}

Keywords: factors, income, peasants, multivariate regression, agriculture

JEL Classification Code: P44, Q11, R10

\section{Introduction}

Vietnam is one of the most vulnerable countries because of natural disasters in the world. Natural disasters include: storms, high tides, floods in rivers and streams, landslides due to heavy rains and droughts, saline intrusion and so on in Vietnam. The damages caused by floods have increased significantly in recent decades. This trend can still continue because of heavy storms and rainfall and consequences of climate change (Viner.D and Bouwer, L. 2006). The effects of climate change also mean that gradual changes in the dangers of hazards can affect Vietnam's ability to achieve millennium goals. These include poverty reduction, gender equality and rural income targets because they have little knowledge about climate change and resources (Monre 2008).

Tra Vinh is a coastal province, located in Mekong Delta, Vietnam, the majority of people depend on agriculture, while the agricultural land fund is limited, the population is increasing, the quality of labor is still low, labor productivity is not high, leading to the low income of the majority of households in rural areas and material difficulties (Ha Hong Nguyen, 2018). Natural disasters and climate change have negatively impacted peasants' incomes in rural areas. Results in 2018, the province's economic growth rate reached $7.39 \%$ compared to 2017 ; in which: agriculture, forestry and fishery increased by $6.21 \%$; industry-construction sector increased by $17.1 \%$; service sector increased $6.9 \%$. Regarding the economic structure of Tra Vinh province: agriculture, forestry and fishery accounted for $33.8 \%$; industry and construction accounted for 30.5 and service sector $31.3 \%$; per capita income is about 1,950 USD / person / year (Tra Vinh Department of Statistics, 2018).

This current affair can put a great pressure on the socio-economic development of Tra Vinh province. Peasants' economy still reveals many limitations: most small-scale, self-sufficient, inefficient and inefficient peasants, peasants' living conduitions are difficult in Tra Vinh province. Therefore, peasants and rural communities are in great need of timely support from the government as well as scientists, studying and proposing appropriate solutions to develop production and improve the life of the agricultural sector, local people (Le Khuong Ninh, 2013). 


\section{Literature Review}

Households' income could be a big concern of domestic and international researchers. For foreign studies, households' income could be affected by many factors. For example, Hossain \& Sen's (1992) study showed that the area size, education level and number of employees and impact on households' incomes in Bangladesh.

Another study in China, Khan (1993) concluded that farm households' income has a close relationship with education levels, capital levels and productive land. In addition, there are many other studies such as the study of Abdulai \& CroleRees (2001), Demurger and colleagues (2010), Janvry \& Sadoulet (2001), Klasen et al. (2013), Yang (2004), Yu \& Zhu (2013) having found the factors affecting the income of farm households in many countries, farm households' income is affected by many factors, including capital, land, education, economic production experience, the number of employees, ability to diversify income and market access opportunities.

Domestic studies also showed similar results. The results of the study by Le Khuong Ninh (2013), the factors affecting the income of the randomly selected households include: age, gender, education, area, demographic, ethnicity, distance, distance from residence to the city center and occupational areas of households. The analysis results show that the factors that have a positive relationship with the income of the households which are the age and education level of the households' heads, ethnicity of the households (Kinh and Khmer), the land area of the households and occupations in which the demographic factor has an opposite effect to the income of households in Mekong Delta.

Besides, the study of Nguyen Quoc Nghi, Bui Van Trinh (2011) showed that: the educational level of the households' heads and the level of labor in the households, the number of income-generating activities and policy approaches are positively correlated with income of 2 groups of households which are Cham and Khmer. In contrast, the number of people and working age negatively affects the income of these two groups. In addition, Nguyen Phan Hong Hanh (2015) also showed that the factors such as education level, gender, age, number of employees and working time, number of economic activities and investment scale affecting households' incomes in Quang Ngai province. The study also showed that the more households are engaged in agro-forestry activities and / or production and business activities, the more incomes are generated.

Mai Van Nam et al (2011), also showed similar results with the above researchers, the authors demonstrated that the higher the education level, the more income the households can earn; The number of households in the family and the areas of cultivated land also affects the incomes of households in Dong Thap, Tra Vinh, An Giang and Can Tho. Some recent studies such as research by Nguyen Lan Duyen (2014) showed that the factors of education level, land area, residence time in the locality, distance from residence to the city center, the amount of loans, interest rates and the number of laborers affecting the incomes of farm households in An Giang. On the other hand, the research results of Chu Thi Kim Loan \& Nguyen Van Huong (2015) also showed that farm resources such as farm size, number and educational level of labor, value production facilities are direct proportions to the incomes of the households in which the scale of production land has the greatest impact. In addition, accessibility to loans, gender of the households' heads and geographical position also impact on the income of households in Thanh Hoa province.

\section{Research Methodologies}

On the basis of the literature review of domestic and foreign empirical studies on factors affecting farmers' incomes. The author inherits and modifies additional groups of factors affecting peasants' incomes, the proposed research model is as follows:

$$
\begin{aligned}
\text { INCOME }=\beta_{0}+ & \beta_{1} \text { AGES }+\beta_{2} \text { GENDER }+\beta_{3} \text { EDUCATION }+\beta_{4} \text { MEMBERS }+\beta_{5} \text { DEPENDENCY RATES + } \\
& \beta_{7} \text { LAND AREAS }+\beta_{8} \text { VALUE MEANS }+\beta_{9} \text { FIELDS }+\beta_{10} \text { TECHNIQUES + } \\
& \beta_{10} \text { EXPERIENCE }+u_{i}
\end{aligned}
$$

In which

+ INCOME is the dependent variable measuring the average annual incomes of the households in the study, the unit is million VND.

$+\beta_{0}$ : Intercept of the regression equation.

$+\beta_{1}, \beta_{2}, \ldots . \beta_{11}$ are the coefficients of the independent variables. 
The independent variables in the model are explained in detail in the Table 1.

Table 1

\begin{tabular}{|c|c|c|c|}
\hline & Content & Bases on selecting variables & Expectations \\
\hline AGES & Household heads'ages & $\begin{array}{c}\text { Nguyen Quoc Nghi, Bui Van } \\
\text { Trinh (2011) }\end{array}$ & + \\
\hline GENDER & Household heads' gender & $\begin{array}{l}\text { Klasen and et al (2013); Mai } \\
\text { Van Nam \& Huynh Thi Dan } \\
\text { Xuan (2011) }\end{array}$ & + \\
\hline EDUCATION & $\begin{array}{c}\text { The highest number of schooling } \\
\text { years of household heads }\end{array}$ & $\begin{array}{l}\text { Yang (2004); Hossain \& Sen } \\
\text { (1992); Khan (1993) }\end{array}$ & + \\
\hline MEMBERS & Family members & $\begin{array}{l}\text { Abdulai \& CroleRees (2001); } \\
\text { Demurger \& et al (2010) }\end{array}$ & + \\
\hline $\begin{array}{l}\text { DEPENDENCY } \\
\text { RATE }\end{array}$ & Dependency rate in the households & $\begin{array}{l}\text { Janvry \& Sadoulet (2001); } \\
\text { Nguyen Lan Duyen (2014). }\end{array}$ & - \\
\hline LAND AREAS & Land area of households & $\begin{array}{l}\text { Chu Thi Kim Loan \& Nguyen } \\
\text { Van Huong (2015); Yu \& Zhu } \\
\text { (2013) }\end{array}$ & + \\
\hline VALUE MEANS & $\begin{array}{l}\text { Currency value of means of } \\
\text { production }\end{array}$ & $\begin{array}{l}\text { Mai Van Nam \& Huynh Thi } \\
\text { Dan Xuan (2011); }\end{array}$ & + \\
\hline FIELDS & $\begin{array}{c}\text { Fields of agricultural production of } \\
\text { households }\end{array}$ & $\begin{array}{c}\text { Nguyen Lan Duyen (2014); } \\
\text { Nguyen Quoc Nghi, Bui Van } \\
\text { Trinh (2011) }\end{array}$ & + \\
\hline TECHNIQUES & Applying techniques to production & $\begin{array}{c}\text { Chu Thi Kim Loan \& Nguyen } \\
\text { Van Huong (2015) }\end{array}$ & + \\
\hline EXPERIENCE & $\begin{array}{l}\text { Number of years involved in } \\
\text { households' agricultural production }\end{array}$ & $\begin{array}{l}\text { Demurger \& et al (2010); Chu } \\
\text { Thi Kim Loan \& Nguyen Van } \\
\text { Huong (2015) }\end{array}$ & + \\
\hline
\end{tabular}

Source: Author's collection, 2019

The primary data are conducted via direct interviews with 170 peasants who grow rice, crops and raise shrimp in Cau Ngang, Tra Cu, Tieu Can and Cang Long districts (Hoang Trong, Chu Nguyen Mong Ngoc, 2008); in Tra Vinh province by a pre-designed questionnaire by sing multivariate regression method to evaluate factors affecting peasants' income.

\section{Research Results}

In order to determine the factors affecting the average annual income of peasants in Tra Vinh province, the results of the multivariate linear regression model are shown in Table 2 below. 
Table 2. Multi-variable regression results

\begin{tabular}{lllll}
\hline Variable names & Coefficients & $\begin{array}{l}\text { Standard errors } \\
\text { Robust }\end{array}$ & Value P & VIF \\
\hline Gender & $-4,80$ & 2,26 & $0,035^{* *}$ & 1,11 \\
Ages & $-0,16$ & 0,07 & $0,029^{* * *}$ & 1,21 \\
Education & 1,01 & 0,40 & $0,012^{* *}$ & 1,12 \\
Members & 2,59 & 0,95 & $0,007^{* * *}$ & 1,49 \\
Dependency rate & $-21,15$ & 6,45 & $0,001^{* * * *}$ & 1,41 \\
Land Areas & 0,00 & 0,00 & 0,347 & 1,11 \\
Techniques & 8,24 & 2,36 & $0,001^{* * *}$ & 1,62 \\
Value Means & 0,01 & 0,02 & 0,553 & 1,03 \\
Experience & $-0,07$ & 0,12 & 0,543 & 1,03 \\
Fields & 33,59 & 2,52 & $0,000^{* * *}$ & 1,12 \\
\hline Constant & 47,51 & 6,45 & 0,000 & \\
\hline & & & & \\
\hline Prob $>$ F & & $\mathbf{0 , 0 0 0}$ & \\
$\mathbf{R}^{2}$ Adjusted & & $\mathbf{0 , 7 0 4 5}$ & $\mathbf{1 7 0}$ & \\
Observed Number & &
\end{tabular}

Note: ${ }^{* *} ;{ }^{* * *}$ corresponding to $5 \%$ and $1 \%$ significance levels

Source: Extracted from research results

To ensure that the model used is appropriate, multi-line tests and variances are implemented. The results of testing the multicollinearity phenomenon showed that the average VIF coefficient was $1.27<10$, so there was no multi-linear phenomenon.

The estimated results of the model show that in 10 independent variables included in the research model, there are 7 variables that have a statistically significant impacting on households' income. Variables include: Gender (household heads'gender), Ages (household heads'ages), Education (education level of household head), members (number of family members), dependency ratio, techniques (applying technical progress), fields (manufacturing sector). These variables have a statistically significant impact at 5\% and $1 \%$. Specifically, sex variables, age and level of impact are statistically significant at $5 \%$ to household income, member variables, dependency ratio, application of technical progress and real estate The impact is statistically significant at $1 \%$ to household income. The remaining variables such as the total area of agricultural production land, the total value of production equipment and the number of years involved in agricultural production are not statistically significant to the average income of households.

There are 3 variables such as gender, age and dependency ratio that adversely affect households' income. The estimation results show that the dependency ratio variable has a negative sign as originally expected, the higher the dependency ratio, the lower the peasants' ability to generate income.

\section{Implications of Policies to Improve Peasants' Income in Tra Vinh Province}

\subsection{Focusing on Seasonal Calendar}

Seasons of agricultural production and fisheries depend on many factors including the main factors which are climate and saline intrusion. In the framework of the project to improve poverty reduction capacity in Tra Vinh province, investment in the system of salinity measurement and salinity forecasting is aimed at serving agricultural and fishery production. The annual seasonal calendar is adjusted to suit the weather forecast and saline intrusion in the province.

\subsection{Focusing on Improving Farming Techniques}

In Tra Vinh, some vegetable production areas, peasants apply water-saving cultivation techniques such as using coatings, drip irrigation and rain sprinkler. The result could be improved in terms of productivity saving water and 
caring time. However, this technique has not been widely applied due to the fact that most peasants are unable to afford this investment in production. Therefore, the State should have a financial policy to prioritize investment in agricultural and fishery production to adapt to climate change.

Households that apply technical advances are more likely to earn income than those who do not apply technical advances. Therefore, Tra Vinh peasants need to participate in many training programs on agricultural extension or training courses to improve agricultural production techniques from organizations, supporting agencies or relevant agencies. At the same time, it could be very vital for peasants to learn about the application of technical advances of households in neighboring areas that have successfully applied in production. Since then, peasants can easily invest in the study and apply technical advances in agriculture to improve income, living conditions and spiritual life as well.

\subsection{Solutions on Income Diversification}

Diversifying income activities are solutions that contribute to increase households' income. When the labor factor from the main source of production labor is limited, increasing other income sources is an inevitable solution to bring income to the family. Diversifying income activities will increase income for households. Therefore, to increase income, it can be very necessary for peasants to diversify income activities. It could be also important for low-income households to actively participate in vocational trainings to create income activities, especially non-agricultural activities to promote available resources of households. It cannot be denied that local authorities strongly develop vocational training classes for peasants and at the same time they also have policies to support production facilities, cooperative economic organizations, businesses, farm owners and so on.

\subsection{Supporting Many More Credit Packages to Support Households}

It could be obvious that production capital is an important factor to decide the production scale of the households, the household economic model to borrow capital for production development of the bank, the model of preferential interest rate credit with the poor, credit through Women's Union and so on have been established and developed widely, but not everyone can borrow because the State has stricted regulations especially for the poor because they are not qualified in many aspects so many households borrowing from outside is very high, which affects production capacity. Therefore, the credit institutions need to borrow money that means the objects of the bank's loans must be the actual households who need capital for production and business, use with the right purposes, not the loan to consume. There should be preferential measures for poor households

\subsection{Gender Factors}

Female household heads are more likely to earn more income, so female households need to be more proactive in managing households' income and expenses. Besides, female householders need to promote the family's production and business plans. At present, the society is growing, the role of women increasingly occupies an important position in the family. In spite of living in rural areas, the ability to understand and apply the progress of science and technology into production and life of women could not inferior to men.

\subsection{Agricultural Production}

Shrimp farmers have a higher income than those who grow rice and crops. Therefore, households growing rice and crops need to expand the production of shrimp farming and select the types of farming and raising scale so as to suit the types and natural conditions, economic conditions of the households. Besides, it is necessary to regularly monitor specialized events with the advice of professional scientists through Tra Vinh channels in order to have the production direction according to the technical standards of farming forms in order to contribute to increase productivity which brings high economic efficiency for households.

\subsection{Focusing on Improving the Level of Peasants}

Household heads with higher educational attainment are higher in income. Therefore, it is very necessary for households heads to improve their education in order to keep up with the speed of modern scientific and technological development to apply to production for greater efficiency. On that basis, it could be vital for peasants to participate in many local cultural courses in order to improve their intellectual levels and participate in mass activities to learn more knowledge, stronger in life and improve. At the same time, farmers can exchange knowledge in production with each other thanks to local community meetings.

\section{Acknowledgements}

This study aims to find out the factors affecting the income of peasants in Tra Vinh province. To conduct research, the authors have been supported from the research group of the Faculty of Economics, Law and Tra Vinh University, 
Viet Nam; Tra Vinh Statistical Office survey group participated in a survey of 170 farmers (or farmers) in 4 districts of Tra Vinh province, Viet Nam. The authors sincerely thanks the enthusiastic support of these research groups.

\section{References}

Abdulai, A., \& CroleRees, A. (2001). Determinants of Income Diversification amongst Rural Households in Southern Mali. Food Policy, 26, 437-452. https://doi.org/10.1016/S0306-9192(01)00013-6

Chu Thi Kim Loan, \& Nguyen Van Huong. (2015). Impact of resources on total income of households in Thanh Hoa province: case studies in Tho Xuan and Ha Trung districts. Journal of Science and Development, Viet nam Agricultural Institute, 13(6), 1051-1060.

Demurger, S., Fournier, M., \& Yang, W. (2010). Rural Households' Decisions towards Income Diversification: Evidence from a Township in Northern China. China Economic Review, 457, 1-13. https://doi.org/10.1016/j.chieco.2010.05.007

Ha Hong Nguyen. (2018). The Study on factors influencing wages: the case of laborers in non-state enterprises in Tra vinh Province, Viet nam. Asian Journal of Science and Technology, 9(9), 8719-8721.

Hoang Trong, \& Chu Nguyen Mong Ngoc. (2008). Data Analysis with SPSS. Hong Duc Publishing House, p.. 23-28.

Hossain, M., \& Sen, B. (1992). Rural poverty in Bangladesh: trends and determinants. Asian Development Review, $10,1-35$.

Janvry, A. D., \& Sadoulet, E. (2001). Income Strategies Among Rural Households in Mexico: The Role of Off-farm Activities. World Development, 29(3), 467-480. https://doi.org/10.1016/S0305-750X(00)00113-3

Khan, A. R. (1993). The determinants of household income in rural China, In: The distribution of Income in China. K. Griffin, \& R. Zhao (Eds.). St. Martin's Press, New York, pp. 95-115. https://doi.org/10.1007/978-1-349-23026-6_4

Klasen, S., Priebe, J., \& Rudolf, R. (2013). Cash Crop Choice and Income Dynamics in Rural Areas: Evidence for Post-crisis Indonesia. Agricultural Economics, 44, 349-364. https://doi.org/10.1111/agec.12015

Le Khuong Ninh. (2013). Official Credit and Income of Households in the Mekong Delta, Proceedings of Scientific Conference. Can Tho University, pp. 147-152.

Mai Van Nam, \& Huynh Thi Dan Xuan. (2011). The analysis affects to income of households poultry breeding in the Mekong Delta. Science Journal, Can Tho University, 17, 87-96.

Nguyen Lan Duyen. (2014). Factors affecting to household incomes in An Giang. Journal of Science, An Giang University, 3(2), 63-69.

Nguyen Phan Hong Hanh, (2015), Analysis of factors affecting household incomes in Tu Nghia district - Quang Ngai province, Master's thesis, Nha Trang University, pp. 28-30.

Nguyen Quoc Nghi, \& Bui Van Trinh. (2011). Factors affecting the income of ethnic minorities in the Mekong Delta. Journal of Science, Can Tho University, 18a, 240-250.

Tra Vinh Provincial Statistical Office. (2018). Reported socio-economic information of Tra Vinh province, pp. 3-5.

Viner, D., \& Bouwer, L. (2006). Adapting to Climate Change: Lessons from Natural Hazards Planning, 23-26.

Yang, D. (2004). Education and Allocative Efficiency: Household Income Growth during Rural Reforms in China. Journal of Development Economics, 74, 137-162. https://doi.org/10.1016/j.jdeveco.2003.12.007

Yu, J., \& Zhu, G. (2013). How Uncertain Is Household Income in China. Economics Letters, 120, 74-78. https://doi.org/10.1016/j.econlet.2013.03.011 